\title{
Prevalence of Borrelia burgdorferi sensu lato and Anaplasma phagocytophilum in questing Ixodes ricinus ticks in relation to the density of wild cervids
}

\author{
Olav Rosef*1, Algimantas Paulauskas² and Jana Radzijevskaja²
}

Address: ${ }^{1}$ Telemark University College, Bø i Telemark, Norway and ${ }^{2}$ Vytautas Magnus University, Kaunas, Lithuania

Email: Olav Rosef* - olav.rosef@hit.no; Algimantas Paulauskas - a.paulauskas@gmf.vdu.lt; Jana Radzijevskaja - j.radzijevskaja@bs.vdu.lt

* Corresponding author

Published: 27 November 2009

Acta Veterinaria Scandinavica 2009, 5 I:47 doi:10.1 I86/175I-0147-5I-47

This article is available from: http://www.actavetscand.com/content/5I///47

(c) 2009 Rosef et al; licensee BioMed Central Ltd.

This is an Open Access article distributed under the terms of the Creative Commons Attribution License (http://creativecommons.org/licenses/by/2.0), which permits unrestricted use, distribution, and reproduction in any medium, provided the original work is properly cited.
Received: 28 April 2009

Accepted: 27 November 2009

\begin{abstract}
Background: Borrelia burgdorferi sensu lato and Anaplasma phagocytophilum have been considered as pathogens in animals and humans. The role of wild cervids in the epidemiology is not clear. We analyzed questing lxodes ricinus ticks collected in spring for these pathogens from sites with high (Fjelløyvær and Strøm) and low density (Tjore, Hinnebu and Jomfruland) of wild cervids to study the spread of the pathogens in questing ticks.
\end{abstract}

Methods: For detection of Anaplasma phagocytophilum a 77-bp fragment in the msp2 gene was used. Detection of Borrelia burgdorferi sensu lato was performed using the FL6 and FL7 primers according to sequences of conserved regions of the fla gene. The OspA gene located on the linear 49-kb plasmid was used as target in multiplex PCR for genotyping. Genospecies-specific primers were used in the PCR for Borrelia burgdorferi sensu stricto, B. afzelii and B. garinii.

Results: Infection rates with Borrelia spp. were significantly lower at Fjelløyvær and Strøm compared to Tjore and Hinnebu; Fjelløyvær vs. Tjore $\left(\chi^{2}=20.27, \mathrm{p}<0.0001\right)$; Fjelløyvær vs. Hinnebu $\left(\chi^{2}=24.04, p<0.0001\right)$; Strøm vs. Tjore $\left(\chi^{2}=11.47, p=0.0007\right)$ and Strøm vs. Hinnebu $\left(\chi^{2}=16.63, p<0.0001\right)$. The Borrelia genospecies were dominated by. $B$. afzelii $(82 \%)$ followed by B. garinii $(9.7 \%)$ and B. burgdorferi sensu stricto $(6.9 \%)$. B. burgdorferi s.s. was only found on the island of Jomfruland. The infection rate of Anaplasma phagocytophilum showed the following figures; Fjelløyvær vs Hinnebu $\left(\chi^{2}=16.27, p=0.0001\right)$; Strøm vs. Tjore $\left(\chi^{2}=13.16, p=0.0003\right)$; Strøm vs. Hinnebu $\left(\chi^{2}=34.71, p<0.0001\right)$; Fjelløyvær vs. Tjore $\left(\chi^{2}=3.19, p=0.0742\right)$ and Fjelløyvær vs. Støm $\left(\chi^{2}=5.06, p=0.0245\right)$. Wild cervids may serve as a reservoir for $A$. phagocytophilum. Jomfruland, with no wild cervids but high levels of migrating birds and rodents, harboured both $B$. burgdorferi s.l. and A. phagocytophilum in questing I. ricinus ticks. Birds and rodents may play an important role in maintaining the pathogens on Jomfruland.

Conclusion: The high abundance of roe deer and red deer on the Norwegian islands of Fjelløyvær and Strøm may reduce the infection rate of Borrelia burgdorferi sensu lato in host seeking Ixodes ricinus, in contrast to mainland sites at Hinnebu and Tjore with moderate abundance of wild cervids. The infection rate of Anaplasma phagocytophilum showed the opposite result with a high prevalence in questing ticks in localities with a high density of wild cervids compared to localities with lower density. 


\section{Background}

Lyme disease, an important arthropod-borne disease of humans in the northern hemisphere, can manifest in many organ systems with symptoms including skin rashes, meningitis, optic neuritis, facial nerve palsy and atrioventricular nodal block. Failure to treat infection promptly and adequately can result in long-term debilitating effect on the patient's health. Three species have been proven to be pathogenic in humans: Borrelia afzelii, $B$. garinii and $B$. burgdorferi sensu stricto [1]. These species appear to be responsible for causing different clinical syndromes [2].

It is well known that Ixodes ticks feed on deer species [3], and that high abundance of Ixodes ticks follows a high abundance of deer [4], but the role of cervid species in the epidemiology of Lyme disease is not completely understood. Although it has been suggested that adaptive immune responses may be involved in the regulation of spirochete transmission [5], the detailed mechanisms underlying differential transmission of the Borrelia genospecies by hosts are unknown. Investigators have concluded that roe deer (Capreolus capreolus) [6] and red deer (Cervus elaphus) [7-9] are incompetent reservoirs for $B$. burgdorferi. Spirochaetes that are sensitive to destruction by the complement system of a particular host species are lysed early in the midgut of the feeding tick and are thereby eliminated by the host [10]. These findings have led to the hypothesis that the host range of spirochaete strain is restricted by its repertoire of genes that encode ligands with the high binding affinities for complement inhibition [7].

Tick-borne fever caused by A. phagocytophilum has been considered a common disease in domestic ruminants along the coast of southern Norway [11]. Several other mammalian species including wild cervids have also been found infected with A. phagocytophilum [12]. Stuen et al. [13] found seroprevalences of granulocytic Ehrlichia spp. in moose (Alces alces) of $43 \%$, red deer $55 \%$, and roe deer $96 \%$ from I. ricinus infested counties in Norway. A study in Switzerland found serological evidence of granulocytic ehrlichial infection in roe deer [14].

Human granulocytic anaplasmosis (HGA) caused by Anaplasma phagocytophilum was first identified in 1990 in a patient who died [15]. HGA is increasingly recognized as an important and frequent cause of fever after tick bite world wide [16], including Scandinavia [17] where Ixodes ticks bite humans. Several Ixodes spp. including I. ricinus, I. arboricola, I. calidonicus, I. frontais, I. hexagonus, I. lividus, I. persulcatus, I. trianguliceps, I. urinae and I. unicavatus have been found in Fennoscandia [18-20] Most human cases occur between June and August and usually appear as an undifferentiated febrile illness. The incubation period following tick-bite is 7-10 days and symptoms include high fever, rigors, generalized myalgias, severe headacke and malaise [16]. Bjöersdorff et al. [17] found a seroprevalence of $15-20 \%$ among 1000 tick-exposed patients (mainly from Sweden and Norway) and concluded a widespread exposure to granulocytic Ehrlichia (now Anaplasma spp.). In Slovenia 3.2\% of I. ricinus were infected with Anaplasma, and they were 99.8\% identical to those previously determined from human patients [21]. The main vector in Europe is I. ricinus. In other continents Zhang et al. [22] found a high seroprevalence rate $(8.8 \%)$ for A. phagocytophilum among 365 farm-workers in China and suggested that human infections with these zoonotic bacteria are frequent and largely unrecognized. A seroprevalence between $2.3 \%$ and 5.6\% was found in different locations in Mongolia and Walder et al. [23] concluded that A. phagocytophilum is endemic. Brown et al. [24] confirmed that woodland rodents can maintain A. phagocytophilum in Great Britain in the absence of other reservoir hosts which suggests that I. trianguliceps is a competent vector.

The aim of the present study was to compare the prevalence of B. burgdorferi s.l. and A. phagocytophilum in I. ricinus ticks in sites with both high and low abundance of roe deer, red deer and moose to evaluate the role of wild cervids in the epidemiology.

\section{Materials and methods Locations and habitats}

Tick samples were collected on two islands on the coast of western Norway: at Strøm (N7048360E498426), on the island of Hitra, and on the island of Fjelløyvær (N7059209E504490) close to the main island Hitra and connected by a bridge. Both islands are largely covered with heath and a mixture of deciduous and pine forest. There are no foxes, but sea gulls and raptorial birds are common, and roe deer and red deer densities are high. There are farms on both islands with grass production and grazing cattle and sheep. Tick samples were also collected at three sites along the southern coast of Norway. These included Tjore, a coastal mainland site (N6463382E473032) located in a mixture of farmland and mixed deciduous, pine and spruce forest, and within $100 \mathrm{~m}$ outside of a red deer enclosure; Hinnebu (N6493848E469418) situated $30 \mathrm{~km}$ from the coast with similar mixed forest but no agriculture or grazing domestic animals; and Jomfruland, an island with agriculture and mixed forest (N6524446E533677). Jomfruland is frequented by many migrating birds and is grazed by sheep and cattle, but contains no wild cervids. Coordinates are given in UTM32 (Euref 89) values. 


\section{Abundance of roe deer, red deer and moose}

We used the official municipal hunting statistics for 2007 for each township involved to estimate the numbers of game animals at each site (Table 1 ). We have defined low density as less than one animal killed per $\mathrm{km}^{2}$ and high density as more than 3 .

\section{Tick collection}

Questing I. ricinus ticks were collected during spring (April-May) 2006-2008 at all five locations using the standard flagging method [25] by drawing a $1 \mathrm{~m}^{2}$ piece of cotton cloth over the vegetation. Ticks attached to the towel were picked with tweezers and placed into $1.5 \mathrm{ml}$ test tube filled with $70 \%$ ethanol.

\section{DNA extraction and detection of Ixodes ricinus}

A modified procedure for extracting DNA with ammonium hydroxide solution $(2.5 \%)$ was performed [26,27]. The lysates were stored at $-20^{\circ} \mathrm{C}$ until use. For I. ricinus identification, the lysates were analysed with species-specific primers IxriF and IxriR resulting in a 150 bp segment of the 5.8 srRNA gene $[28,29]$. This PCR reaction was further used as positive control. DNA bands were stained with ethidium bromide and visualised by UV transillumination (EASY Win32, Herolab, Germany).

\section{Detection of Borrelia burgdorferi sensu lato}

The occurrence of Borrelia burgdorferi s.l. in ticks was determined by polymerase chain reaction by using the oligonucleotide primers FL6 and FL7 according to sequences of conserved regions of the fla gene [26]. PCR products were resolved by $1.5 \%$ agarose gel electrophoresis with addition of ethidium bromide and visualized under UV light (EASY Win32, Herolab, Germany). The achieved specific amplification products of 276 base pairs (bp) were considered a positive result. Negative and positive controls were included in all runs.

\section{Genotyping of Borrelia burgdorferi sensu lato}

The OspA gene located on the linear 49-kb plasmid was used as target in multiplex PCR according to Demaer-

Table I: Number of animals killed by hunting per $\mathrm{km}^{2}$ (hunting statistics for 2007)

\begin{tabular}{lllll}
\hline & Red deer & Roe deer & Moose & Total \\
\hline Fjelløyvær & $0.05(\mathrm{I})^{\mathrm{a}}$ & $8.62(\mathrm{I} \mathrm{I})$ & $0^{*}$ & 8.67 \\
Strøm & $\mathrm{I} .94(846)$ & $\mathrm{I} .18(5 \mathrm{I})$ & $0^{*}$ & 3.12 \\
Hinnebu & $0.05(30)$ & $0.33(198)$ & $0.3 \mathrm{I}(194)$ & 0.69 \\
Tjore & $0.02(6)$ & $0.56(528)$ & $0.17(194)$ & 0.75 \\
Jomfruland & $0^{* *}$ & $0^{* *}$ & $0^{*}$ & 0
\end{tabular}

aThe numbers in parentheses represent the total number of killed animals.

*Moose is absent.

**Red deer and roe deer are absent. shalck et al. [30]. Genospecies-specific primers were used in the PCR for B. burgdorferi sensu stricto, B. afzelii and B. garinii. PCR amplification products were resolved onto $2.0 \%$ agarose gel electrophoresis and visualized under UV light. The specific products of 544 bp (B. burgdorferi s.s.) 345 bp (B. garinii) and 189 bp (B. afzelii) were considered to represent positive results. Negative and positive controls were included in all runs.

\section{Detection of Anaplasma phagocytophilum}

I. ricinus questing ticks were examined for the prevalence of A. phagocytophilum by using the species-specific primers ApMSP2f, ApMSP2r, and TaqMan probe ApMsp2p-FAM, as described by Courtney et al. [31]. A 77-bp fragment in the $m s p 2$ gene of $A$. phagocytophilum was amplified. PCR was performed using TaqMan Master Mix (Applied Biosystems, CA) in a quantitative thermal cycler (iCycler, BioRad Laboratories, Inc., Hercules, CA). Negative and positive controls were included in all runs.

\section{Statistics}

The data were analysed statistically by means of Pearson's $\chi^{2}$ test by using the statistical package STATISTICA for WINDOWS 5.5. We compared the mean isolation rate of B. burgdorferi s.l. and A. phagocytophilum for 2006-2008 in sites with different densities of wild cervids.

\section{Results}

The highest density of wild cervids was Fjelløyvær followed by Strøm (Table 1). No Borrelia was detected in questing ticks in Fjelløyvær, and low values in Strøm during the three year period (Table 2). The infection rates were significantly lower in areas with high density of wild cervids compared to sites with low density: Fjelløyvær vs. Tjore $\left(\chi^{2}=20.27, \mathrm{p}<0.0001\right)$; Fjelløyvær vs. Hinnebu $\left(\chi^{2}\right.$ $=24.04, \mathrm{p}<0.0001)$; Strøm vs. Tjore $\left(\chi^{2}=11.47, \mathrm{p}=\right.$ $0.0007)$ and Strøm vs. Hinnebu $\left(\chi^{2}=16.63, \mathrm{p}<0.0001\right)$. There were significantly lower values on Fjelløyvær vs. Jomfruland $\left(\chi^{2}=10.66, \mathrm{p}=0.0011\right)$; Fjelløyvær vs Strøm $\left(\chi^{2}=4.26, \mathrm{p}=0.0390\right)$ and Hinnebu vs. Jomfruland $\left(\chi^{2}=\right.$ $6.56, \mathrm{p}=0.0104)$, but no significant difference between Tjore vs. Jomfruland $\left(\chi^{2}=3.2, \mathrm{p}=0.0735\right)$; Strøm vs. Jomfruland $\left(\chi^{2}=3.24, \mathrm{p}=0.0719\right)$ and Hinnebu vs. Tjore $\left(\chi^{2}=0.27, \mathrm{p}=0.6006\right)$. The distribution of genospecies is shown in Table 3. B. afzelii dominated with $82 \%$ followed by B. garinii (9.7\%) and B. burgdorferi s.s. (6.9\%). B. burgdorfereri s.s. was only found on the island of Jomfruland.

The prevalence of A. phagocytophilum infections in questing ticks (Table 4) was significantly higher in localities with high density of wild cervids compared to localities with lower density (Table 1): Fjelløyvær vs. Hinnebu $\left(\chi^{2}=\right.$ 16.27, $\mathrm{p}=0.0001)$; Fjelløyvær vs. Støm $\left(\chi^{2}=5.06, \mathrm{p}=\right.$ $0.0245)$; Strøm vs. Tjore $\left(\chi^{2}=13.16, \mathrm{p}=0.0003\right)$ and Strøm vs. Hinnebu $\left(\chi^{2}=34.71, \mathrm{p}=0.0000\right)$. The figures 
Table 2: Prevalence of Borrelia burgdorferi sensu lato in questing Ixodesricinus ticks 2006, 2007 and 2008.

\begin{tabular}{|c|c|c|c|c|c|c|c|c|c|c|c|c|c|}
\hline \multirow[t]{3}{*}{ Locations } & \multirow[t]{3}{*}{ Years } & \multicolumn{3}{|c|}{ Female } & \multicolumn{3}{|c|}{ Male } & \multicolumn{3}{|c|}{ Nymph } & \multicolumn{3}{|c|}{ Total } \\
\hline & & \multirow[t]{2}{*}{$\mathbf{N}$} & \multicolumn{2}{|c|}{ Prevalence } & \multirow[t]{2}{*}{$\mathbf{N}$} & \multicolumn{2}{|c|}{ Prevalence } & \multirow[t]{2}{*}{$\mathbf{N}$} & \multicolumn{2}{|c|}{ Prevalence } & \multirow[t]{2}{*}{$\mathbf{N}$} & \multicolumn{2}{|c|}{ Prevalence } \\
\hline & & & $\mathbf{n}$ & $\%$ & & $\mathbf{n}$ & $\%$ & & $\mathbf{n}$ & $\%$ & & $\mathbf{n}$ & $\%$ \\
\hline \multirow{4}{*}{ Hitra, Fjelløyvær } & 2008 & 9 & 0 & 0 & 8 & 0 & 0 & 43 & 0 & 0 & 60 & 0 & 0 \\
\hline & 2007 & 23 & 0 & 0 & 27 & 0 & 0 & 30 & 0 & 0 & 80 & 0 & 0 \\
\hline & 2006 & 2 & 0 & 0 & 6 & 0 & 0 & 56 & 0 & 0 & 64 & 0 & 0 \\
\hline & & & & & & & & & & & 204 & 0 & 0 \\
\hline \multirow[t]{4}{*}{ Hitra, Strøm } & 2008 & 5 & 0 & 0 & 7 & I & 14.3 & 40 & 0 & 0 & 52 & 1 & 1.9 \\
\hline & 2007 & 40 & 0 & 0 & 32 & 0 & 0 & 16 & 0 & 0 & 88 & 0 & 0 \\
\hline & 2006 & 5 & 1 & 20 & 3 & 0 & 0 & 89 & 3 & 3.4 & 97 & 4 & 4.1 \\
\hline & & & & & & & & & & & 237 & 5 & 2.1 \\
\hline \multirow[t]{4}{*}{ Tjore } & 2008 & 24 & 1 & 4.2 & 14 & 0 & 0 & 20 & 2 & 10 & 58 & 3 & 5.2 \\
\hline & 2007 & 19 & 2 & 10.5 & 23 & 3 & 13 & 38 & 1 & 2.6 & 80 & 6 & 7.5 \\
\hline & 2006 & 4 & 1 & 25 & 4 & 0 & 0 & 16 & 7 & 43,8 & 24 & 8 & 33.3 \\
\hline & & & & & & & & & & & 162 & 17 & 10.5 \\
\hline \multirow[t]{4}{*}{ Hinnebu } & 2008 & 31 & 3 & 9.7 & $4 I$ & 3 & 7.3 & 7 & 0 & 0 & 79 & 6 & 7.6 \\
\hline & 2007 & 52 & 15 & 28.8 & 57 & 4 & 7 & 6 & 0 & 0 & 115 & 19 & 16.5 \\
\hline & 2006 & 42 & 4 & 9.5 & 32 & 4 & 12.5 & 32 & 4 & 12.5 & 106 & 12 & 11.3 \\
\hline & & & & & & & & & & & 300 & 37 & 11.8 \\
\hline \multirow[t]{4}{*}{ Jomfruland } & 2008 & 29 & 3 & 10.3 & 30 & 0 & 0 & 20 & 0 & 0 & 79 & 3 & 3.8 \\
\hline & 2007 & 30 & 3 & 10 & 20 & 2 & 10 & 22 & 0 & 0 & 72 & 5 & 6.9 \\
\hline & 2006 & 8 & 0 & 0 & 8 & 0 & 0 & 76 & 7 & 9.2 & 92 & 5 & 5.4 \\
\hline & & & & & & & & & & & 243 & 13 & 5.3 \\
\hline
\end{tabular}

$\mathrm{N}=$ number of tested ticks; $\mathrm{n}=$ number of infected ticks

for Hinnebu vs. Tjore was $\left(\chi^{2}=5.07, \mathrm{p}=0.0243\right)$; Hinnebu vs. Jomfruland $\left(\chi^{2}=30.73, \mathrm{p}=0.000\right)$ and Jomfruland vs. Tjore $\left(\chi^{2}=10.97, \mathrm{p}=0.0009\right)$. There was one exception, with no significant difference between Fjelløyvær and Tjore where a high level of $A$. phagocytophilum was detected in $2008\left(\chi^{2}=3.19, \mathrm{p}=0.0742\right)$ (Table 4). There were no significant difference between Strøm and Jomfru- land $\left(\chi^{2}=0.38, \mathrm{p}=0.54\right)$, or Fjelløyvær and Jomfruland $\left(\chi^{2}=3.78, \mathrm{p}=0.0519\right)$.

\section{Discussion}

Kurtenbach et al. [5] showed that sera from red deer were indiscriminating borrealicidal for the three human pathogenic strains. The reservoir incompetence of roe deer [32]

Table 3: Borrelia burgdorferi sensu lato genospecies in questing Ixodes ricinus ticks.

\begin{tabular}{|c|c|c|c|c|}
\hline Locations & $\begin{array}{l}\text { B.afzelii } \\
\text { n/N (\%) }\end{array}$ & $\begin{array}{l}\text { B.garinii } \\
\text { n/N (\%) }\end{array}$ & $\begin{array}{l}\text { B.burgdorferi s.s. } \\
\text { n/N (\%) }\end{array}$ & $\begin{array}{l}\text { B.burgdorferi s.s.+ B.afzelii } \\
\text { n/N (\%) }\end{array}$ \\
\hline Hitra, Strøm & $4 / 5(80)$ & I/5 (20) & $0 / 5(0)$ & $0 / 5(0)$ \\
\hline Tjore & $13 / 17(76.5)$ & $4 / 17(23.5)$ & $0 / 17(0)$ & $0 / 17(0)$ \\
\hline Hinnebu & $35 / 37(94.6)$ & $2 / 37(5.6)$ & $0 / 37(0)$ & $0 / 37(0)$ \\
\hline Jomfruland & $7 / 13(53.8)$ & $0 / 13(0)$ & $5 / 13(38.5)$ & $1 / 13(7.7)$ \\
\hline Total & $59 / 72(82)$ & $7 / 72(9.7)$ & $5 / 72(6.9)$ & $1 / 72(1.4)$ \\
\hline
\end{tabular}

$\mathrm{N}=$ number of tested ticks; $\mathrm{n}=$ number of infected ticks; $(\%)$ - prevalence of infection 
Table 4: Prevalence of Anaplasma phagocytophilum in questing Ixodesricinus ticks 2006, 2007 and 2008.

\begin{tabular}{|c|c|c|c|c|c|c|c|c|c|c|c|c|c|}
\hline \multirow[t]{3}{*}{ Locations } & \multirow[t]{3}{*}{ Years } & \multicolumn{3}{|c|}{ Female } & \multicolumn{3}{|c|}{ Male } & \multicolumn{3}{|c|}{ Nymphs } & \multicolumn{3}{|c|}{ Total } \\
\hline & & \multirow[t]{2}{*}{$\mathbf{N}$} & \multicolumn{2}{|c|}{ Prevalence } & \multirow[t]{2}{*}{$\mathbf{N}$} & \multicolumn{2}{|c|}{ Prevalence } & \multirow[t]{2}{*}{$\mathbf{N}$} & \multicolumn{2}{|c|}{ Prevalence } & \multirow[t]{2}{*}{$\mathbf{N}$} & \multicolumn{2}{|c|}{ Prevalence } \\
\hline & & & $\mathbf{n}$ & $\%$ & & $\mathbf{n}$ & $\%$ & & $\mathbf{n}$ & $\%$ & & $\mathbf{n}$ & $\%$ \\
\hline \multirow{4}{*}{ Hitra, Fjelløyvær } & 2008 & 9 & 0 & 0 & 8 & 0 & 0 & 42 & 2 & 4.8 & 59 & 2 & 3.4 \\
\hline & 2007 & 23 & 4 & 17.4 & 24 & 3 & 12.5 & 30 & 2 & 16.7 & 77 & 12 & 15.6 \\
\hline & 2006 & 2 & 1 & 50 & 6 & 0 & 0 & 56 & 2 & 3.6 & 64 & 3 & 4.7 \\
\hline & & & & & & & & & & & 200 & 17 & 8.5 \\
\hline \multirow[t]{4}{*}{ Hitra, Strøm } & 2008 & 5 & 0 & 0 & 7 & 2 & 28.6 & 40 & 11 & 27.5 & 52 & 13 & 25 \\
\hline & 2007 & 40 & 9 & 22.5 & 35 & 9 & 25.7 & 33 & 3 & 9.1 & 108 & 21 & 19.4 \\
\hline & 2006 & 5 & 1 & 20 & 3 & 1 & 33.3 & 89 & 8 & 8.9 & 97 & 10 & 10.3 \\
\hline & & & & & & & & & & & 257 & 44 & 17.1 \\
\hline \multirow[t]{4}{*}{ Tjore } & 2008 & 24 & 3 & 12.5 & 14 & 0 & 0 & 20 & 2 & 0.8 & 58 & 5 & 8.6 \\
\hline & 2007 & 19 & 0 & 0 & 22 & 0 & 0 & 21 & 0 & 0 & 63 & 0 & 0 \\
\hline & 2006 & 4 & 0 & 0 & 4 & 0 & 0 & 16 & 0 & 0 & 24 & 0 & 0 \\
\hline & & & & & & & & & & & 145 & 5 & 3.4 \\
\hline \multirow[t]{4}{*}{ Hinnebu } & 2008 & 31 & 1 & 3.2 & 41 & 0 & 0 & 7 & 0 & 0 & 79 & 1 & 1.3 \\
\hline & 2007 & 27 & 0 & 0 & 18 & 0 & 0 & 5 & 0 & 0 & 50 & 0 & 0 \\
\hline & 2006 & 42 & 0 & 0 & 32 & 0 & 0 & 32 & 0 & 0 & 106 & 0 & 0 \\
\hline & & & & & & & & & & & 235 & 1 & 0.4 \\
\hline \multirow[t]{4}{*}{ Jomfruland } & 2008 & 29 & 6 & 20.7 & 40 & 10 & 25 & 57 & 13 & 22.4 & 126 & 29 & 23.0 \\
\hline & 2007 & 50 & 8 & 16 & 32 & 3 & 9.4 & 49 & 4 & 8.2 & $|3|$ & 15 & 11.5 \\
\hline & 2006 & 8 & 1 & 12.5 & 8 & 1 & 12.5 & 75 & 6 & 8 & 91 & 8 & 8.7 \\
\hline & & & & & & & & & & & 348 & 52 & 14.9 \\
\hline
\end{tabular}

$\mathrm{N}=$ number of tested ticks; $\mathrm{n}=$ number of infected ticks

and red deer [9] correlates with this borrealicidic effect. Complement appears relevant to host incompetency for Borrelia, and this carries over to prevent tick infection and lyse the spirochetes early in the midgut of the feeding tick, and are thereby eliminated by the host [10]. Low levels of B. burgdorferi s.l. in ticks werre found in both sites on Hitra (Table 2). No infected ticks were detected in Fjelløyvær during the three year period, and only a low level of $B$. burgdorferi s.l. in $2006(4.1 \%)$ and in $2008(1.9 \%)$ at Strøm (Table 2). Fjelløyvær has a very high abundance of roe deer, but red deer are nearly absent (Table 1). Strøm has a high abundance of both red and roe deer. We believe that the main route for the tick cycles is red deer and roe deer at Strøm and Fjelløyvær. The high abundance of deer gives high levels of ticks, but the serum incompetence will reduce both the infection in ticks and the risk of Lyme disease transmission.
This contrasts with the figures at Hinnebu where the infection rates with $B$. burgdorferi s.l. were $10 \%, 16.5 \%$ and $7.6 \%$ in 2006-2008 (Table 2). Hinnebu is forest-covered with a low density of moose and roe deer, and a low abundance of red deer. Harvest statistics show a much lower combined density of wild cervids at Hinnebu than at Fjelløyvær and Strøm (Table 1). Tjore has low densities of red deer and moose, and a moderate density of roe deer. Ticks collected outside a fenced red deer farm indicated that the presence of the farm had no influence on the level of $B$. burgdorferi s.l. The overall infection rates in ticks were $33.3 \%$ in $2006,6.9 \%$ in 2007 and $5.2 \%$ in 2008 . The capacity of deer to act as reservoirs for B. burgdorferi s.l., is controversial $[33,34]$. However, our results clearly support the idea that wild cervids are incompetent reservoirs. Our results showed that the infection rates in questing ticks were significantly lower in areas with a high density 
of wild cervids (Fjelløyvær and Strøm) compared to sites with low density (Tjore and Hinnebu) (Tables 1 and 2).

B. afzelii genospecies from ticks dominated with $82 \%$ as shown in Table 3. This genospecies is related to rodents $[7,35,36]$. B. garinii was detected in Strøm, Tjore and Hinnebu while B. burgdorferi s.s was found on questing ticks from Jomfruland. Though Jomfruland has no wild cervids, it does have grazing domestic animals, plus migrating birds during spring and autumn. In this site we investigated 49 A. flavicollis mice and found an infection rate of $12.2 \%$ with B. burgdorferi s.l. Of 490 I. ricinus ticks feeding on rodents, 17 (3.5\%) were infected with $B$. burgdorferi s.l., and B. burgdorferi s.l. was also detected in $15.3 \%(\mathrm{n}=262)$ of ticks feeding on blackbirds Turdus merula [Rosef, unpublished]. It seems that birds and rodents play an important role in maintaining Borrelia infection on Jomfruland. The prevalence of B. burgdorferi s.l. in ticks showed significantly lower values on Fjelløyvær than Jomfruland and Hinnebu than Jomfruland. In comparison there was no significance between Tjore and Jomfruland and Strøm and Jomfruland.

In contrast to infection with $B$. burgdorferi s.l., cervids are important reservoirs for A. phagocytophilum. Stuen et al. [13] found an overall high seroprevalence for A. phagocytophilum (formerly granulocytic Ehrlichia spp.) in moose, red deer and roe deer in Norway with 43\%, 55\% and 96\% respectively. Experimental Anaplasma infection in red deer has shown subclinical persistent infection [37]. These wild ruminants are exposed to A. phagocytophilum and comprise the most widespread tick-borne infection in animals in Europe [38]. In Wisconsin, Michalski et al. [39] found a prevalence in ticks between $5.8 \%$ and $8.9 \%$, and in white-tailed deer between $11.5 \%$ and $26 \%$ using PCR and DNA sequencing. A paretic condition in an A. phagocytophilum infected roe deer calf [40] and ehrlichiosis in a moose calf [12] has been observed in Norway. The high level of infected ticks at Fjelløyvær and Strøm (Table 4) not surprisingly shows that roe deer and red deer probably are competent reservoirs and vehicles for this bacterium.

A low prevalence of A. phagocytophilum in ticks from Hinnebu and Tjore was found in 2008 (Table 4) but it could not be detected in 2006 and 2007. The prevalence of $A$. phagocytophilum in host seeking I. ricinus ticks in Norway varied from zero to $19.4 \%$ in 18 sites investigated, with the highest prevalence occurring in Hitra [41]. The prevalence of A. phagocytophilum infections in ticks was significantly higher in localities with high density of wild cervids (Fjelløyvær and Strøm) compared to localities with lower densities (Tjore and Hinnebu) (Tables 1 and 4). An exception that cannot be explained occurred in 2008 when the prevalence of A. phagocytophilum was high in Tjore and low in Fjellværøy.

In Europe B. burgdorferi s.l. and A. phagocytophilum are transmitted by the same vector (I. ricinus), but it is unclear whether both pathogens use the same range of host species as reservoirs on a smaller scale. In Europe, studies conducted in the United Kingdom, Switzerland, Germany and the Czech Republic demonstrated that small rodents including Myodes glareolus, Microtus arvalis, Microtus agrestis, Apodermus flavicollis and Apodermus sylvaticus harbored A. phagocytophilum and were suggested as potential reservoirs [24,42-45]. In a study in Northern England, Bown et al. [42] described the maitainance of the enzootic cycle of A. phagocytophilum in the rodent -I. trianguliceps system. In a study conducted in Germany [43] A. phagocytophilum was detected in $13.4 \%$ of red bank voles and $6.2 \%$ of field voles. In contrast, only $0.5 \%$ of A. flavicollis was A. phagocytophilum positive. Investigations from Switzerland, England and Norway have shown that deer and sheep can be reservoir hosts $[14,40,46]$. Migrating birds have also been considered important in the dispersal of $A$. phagocytophilum infected I. ricinus in Europe and in the distribution of HGA $[17,38]$.

A. phagocytophilum could not be detected in 49 rodents and in $24 \mathrm{I}$. ricinus nymphs feeding on rodents investigated on Jomfruland, possibly because I. trianguliceps is the main vector for Anaplasma in rodents [24,42]. A. phagocytophilum was found in ticks feeding on birds on Jomfruland [47]. This indicates that birds are involved in the maintenance of Anaplasma here, but rodents play only a minor role in the epidemiology of Anaplasma in the investigated areas in Norway. Hinnebu is located inland and is not on the main route of migrating birds. Tjore is near the coast, but not a typical site for migrating birds. Migrating birds, however, may play an important role as hosts for I. ricinus larvae and nymphs and probably for the infection route of Anaplasma (as for B. burgdorferi s.l.) [47]. On the island of Jomfruland the figures for A. phagocytophilum were $8.7 \%, 11.5 \%$ and $23 \%$ in 2006-2008. However, A. phagocytophilum was found on ticks feeding on birds in 33 out of 308 ticks investigated [47] on Jomfruland and also in questing ticks (Table 4). This indicates that birds are a possible reservoir. Both $B$. burgdorferi s.l. and A. phagocytophilum were found in ticks feeding on migrating birds and in questing ticks.

\section{Conclusion}

A high prevalence of $A$. phagocytophilum in questing ticks in sites with high abundance of deer ( $>3$ killed animals per $\mathrm{km}^{2}$ ) and low prevalence of B. burgdorferi s.l. was found, and we conclude that deer may be important reservoirs of A. phagocytophilum and incompetent carriers for 
B. burgdorferi s.l., thereby reducing the infection rate on questing Ixodes ricinus ticks.

\section{Competing interests}

The authors declare that they have no competing interests.

\section{Authors' contributions}

$\mathrm{OR}$ and $\mathrm{AP}$ have designed and performed the experimental study. OR has drafted the manuscript. JR has carried out the statistical and molecular genetic analyses. All authors read and approved the final manuscript

\section{Acknowledgements}

We thank the Lithuanian State Science and Studies Foundation and Telemark University College for financial support.

\section{References}

I. Wang G, van Dam AP, Schwartz I, Dankert J: Molecular typing of Borrelia burgdorferi sensu lato: taxonomic, epidemiological, and clinical implications. Clin Microbiol Rev I999, I 2:633-653.

2. Balmelli T, Piffaretti JC: Association between clinical manifestations of Lyme disease and different species of Borrelia burgdorferi sensu lato. Res Microbiol 1995, I 46:329-340.

3. Lane RS, Piesman J, Burgdorfer W: Lyme borreliosis: Relation of its causative agent to its vectors and hosts in North America and Europe. Annu Rev Entomol 1991, 36:587-609.

4. Wilson ML, Telford SR, Piesman J, Spielman A: Reduced abundance of immature Ixodes dammini (Acari:Ixodidae) following elimination of deer. J Med Entomol 1988, 25:224-228.

5. Kurtenbach K, Sewell HS, Ogden NH, Randolph SE, Nuttal PA: Serum complement sensitivity as a Key factor in Lyme disease ecology. Infect Immun 1998, 66: I248-I25I.

6. Thomas G, Jaenson T, Tällerklint $L$ : Incompetence of roe deer as reservoirs of the Lyme borreliosis spirochete. J Med Entomol 1992, 29:813-817.

7. Kurtenbach K, De Michelis S, Etti S, Schäfer SM, Sewell HS, Brade V, Kraczy P: Host association of Borrelia burgdorferi sensu latothe key role of host complement. Trends Microbiol 2002, 10:74-79.

8. Matuschka F-R, Heiler M, Eiffert H, Fisher P, Lotter H, Spielman A: Diversionary role of hoofed game in the transmission of Lyme disease spirochetes. Am J Trop Med Hyg 1993, 48:693-699.

9. Telford SR, Mather TN, Moore SI, Wilson ML, Spielman A: Incompetence of deer as reservoirs of the Lyme disease spirochete. Am J Trop Med Hyg 1988, 39: 105-109.

10. Kurtenbach K, Haninková K, Tsao Jl, Margos G, Fish D, Ogden NH: Fundamental process in the evolutionary ecology of Lyme borreliosis. Nat Rev Microbiol 2006, 4:660-669.

II. Stuen S: Sjodogg (tick-borne fever) - a historical review. Nor Vet Tidsskr 1998, i 1 0:703-706. in Norwegian

12. Jenkins A, Handeland S, Stuen S, Schouls L, Pol I Van De, Meen RT, Kristiansen BE: Ehrlichiosis in a moose calf. J Wild Dis 2001, 37:20I-203.

13. Stuen S, Åkerstedt J, Bergstrøm K, Handeland K: Antibodies to granulocytic Ehrlichia in moose, red deer, and roe deer in Norway. J Wild Dis 2002, 38: I-6.

14. Liz JS, Sumner JW, Pfister K, Brossard M: PCR detection and serological evidence of granulocytic ehrlichial infection in roe deer (Capreolus capreolus) and chamois (Rupicapra rupicapra). J Clin Microbiol 2002, 40:892-897.

15. Chen S-M, Dumler JS, Bakken JS, Walker D: Identification of granulocytotropic Ehrlichia species as the etiologic agent of human disease. J Clin Microbiol 1994, 32:589-595.

16. Parola $P$, Davoust $B$, Raoult D: Tick- and flea-borne rickettsial emerging zoonoses. Vet Res 2005, 36:469-492.

17. Bjöersdorff A, Berglund J, Kristiansen BE, Söderström C, Eliasson I: Varying clinical picture and course of human granulocytic ehrlichiosis. Twelve Scandinavian cases of the new tick borne zoonosis are presented. Läkartidningen 1999, 96:4200-42004. in Swedish
18. Mehl R: The distribution and host relations of Norwegian ticks (Acari, Ixodides). Norw J Entomol 1983, 30:46-5I.

19. Jaenson TGT, Tällerklint L, Lundquist L, Olsén B, Chirico J, Mejlon H: Geographical distribution, host associations and vector roles of ticks (Acari, Ixodidae \& Argasidae) in Sweden. J Med Ento$\mathrm{mol}$ 1994, $31: 240-256$.

20. Jääskeläinen AE, Tikkakoski T, Uzcátegui NY, Alekseev AN, Vaheri A, Vapalahti O: Siberian subtype Tickborne Encephalitis Virus, Finland. Emerg Infect Dis 2006, 12:1568-157I.

21. Petrovec M, Sumner JW, Nicholson WL, Childs JE, Strle F, Barlič J, Lotrič-Furlan S, Avšič Županc T: Identity of Ehrlichial DNA sequences derivered from lxodes ricinus ticks with those obtained from patients with human granulocytic ehrlichiosis in Slovenia. J Clin Microbiol 1999, 37:209-210.

22. Zhang L, Shan A, Mathew B, Yin J, Fu X, Zhang J, Lu J, Xu J, Dumler S: Rickettsial seroepidemiology among farm workers, Tianjin, People's Republic of China. Emerg Infect Dis 2008, I 4:938-940.

23. Walder G, Lkhamsuren E, Shagdar A, Bataa J, Batmunckh T, Orth D, Heinz FX, Danichova A, Khasnatinov MA, Würzner R, Dierich MP: Serological evidence for tick borne encephalitis, borreliosis, and human granulocytic anaplasmosis in Mongolia. Int J Med Microbiol 2006, 296:69-75.

24. Bown KJ, Begon M, Bennett M, Woldehiwet Z, Ogden NH: Seasonal dynamics of Anaplasma phagocytophila in a rodent-tick (Ixodes trianguliceps) system, United Kingdom. Emerg Infect Dis 2003, 9:63-70.

25. Hillyard R: Ticks of North-West Europe. Synopsis of the British Fauna (New Series). Volume 58. Edited by: Barnes RSK, Crothers JH. The Natural Historical Museum, London : 178.

26. Stañczak J, Racewics M, Kubica-Biernat B, Kruminis-Łozowska W, Dabrownski J, Adamczyk A, Markowska M: Prevalence of Borrelia burgdorferi sensu lato in Ixodes ricinus ticks (Acari, Ixodidae) in different Polish woodlands. Ann Agr Environ Med 1999, 6:127-132.

27. Ambrasienë D, Turčinavičiene J, Vaščilo I, Žygutiene M: The prevalence of Borrelia burgdorferi in Ixodes ricinus ticks detected by PCR in Lithuania. Vet Med Zoot 2004, 28:45-47.

28. Fukanaga M, Yabuki M, Hamase A, Oliver J, Nakao M: Molecular phylogenetic analysis of Ixodic ticks based on the ribosomal DNA spacer, internal transcribed spacer, sequenses. J Parasit 2000, 86:38-43.

29. Radzijevskaja j, Indriulytë $R$, Paulauskas A, Ambrasienë $D$, Turčinavičienë J: Genetic polymorphism study in Ixodes ricinus L. ticks populations of Lithuania using RAPD markers. Acta Zool Lith 2005, 15:34I-348.

30. Demaerschalck I, Massaoud A, Kesel M, Hoyois B, Lobet $Y$, Hoet , Bigaignon G, Bollen A, Godfroid E: Simultaneous presence of different Borrelia burgdorferi genospecies in biological fluids of Lyme disease patients. J Clin Microbiol 1995, 33:602-608.

31. Cortney JW, Kostelnik LM, Zeidner NS, Massung RF: Multiplex real-time PCR for detection of Anaplasma phagocytophilum 2004. and Borrelia burgdorferi. J Clin Microbiol 2004, 42:3164-3168.

32. Jaenson TGT, Tällerklint L: Incompetence of roe deer as reservoirs of the Lyme borreliosis spirochete. J Med Entmol 1992, 29:8I3-8I7.

33. Oliver JH, Stallknecht D, Chandler FW, James AM, McGuire BS, Howerth $\mathrm{E}$ : Detection of Borrelia burgdorferi in laboratoryrelated Ixodes dammini (Acari:Ixodidae) fed on experimentally inoculated white-tailed deer. J Med Entomol 1992, 29:980-984.

34. Pichon B, Mousson L, Figureau C, Rodhain F, Perez-Eid C: Density of deer in relation to the prevalence of Borrelia burgdorferi s.l. in Ixodes ricinus nymhs in Ramboillet forest, France. Exp Appl Acarol 1999, 23:267-275.

35. Hanincová K, Schäfer S, Etti S, Sewell H, Taragelova V, Ziak D, Labuda $\mathrm{M}$, Kurtenbach K: Association of Borrelia afzelii with rodents in Europe. Parasitology 2003, I 26: I I-20.

36. Humair PF, Gern L: The wild hidden face of Lyme borreliosis in Europe. Microbes Infect 2000, 2:915-922.

37. Stuen S, Handeland K, Frammarsvik T, Bergstrøm K: Experimental Ehrlichia phagocytophila infection in red deer (Cervus elaphus). Vet Rec 200I, I 49:390-392.

38. Stuen S: Anaplasma phagocytophilum - the most widespread tick-borne infection in animals in Europe. Vet Res Comm 2007, 3 I (suppl):79-84. 
39. Michalski M, Rosenfield C, Erickson M, Selle R, Bates K, Essar D, Massung R: Anaplasma phagocytophilum in central and western Wisconsin: a molecular survey. Parasitol Res 2006, 99:694-699.

40. Stuen S, Moum T, Bernhoft A, Sirkka V: A paretic condition in an Anaplasma phagocytophilum infected roe deer. J Wildl Dis 2006, 42: $170-174$.

41. Rosef $O$, Radzijevskaja J, Paulauskas A, Haslekås C: The prevalence of Anaplasma phagocytophilum in host-seeking Ixodes ricinus ticks in Norway. Clin Microbiol Infect 2009, I 5(Suppl I):.

42. Bown KJ, Begon M, Bennett M, Birtles RJ, Burthe S, Lambin X, Telfer $\mathrm{S}$, Woldehiwet Z, Ogden NH: Sympatric Ixodes trianguliceps and Ixodes ricinus ticks feeding on field voles (Microtus agretis): Potential for increased risk of Anaplasma phagocytophilum in the United Kingdom? Vector-Borne Zoonot Dis 2006, 6:404-4I 0 .

43. Hartelt K, Pluta S, Oehme R, Kimmig P: Spread of ticks and tickborne diseases in Germany due to global warming. Parasitol Res 2008, I03(Suppl I):.

44. Hulínská D, Langrová K, Pejčoch M, Pavlásek I: Detection of Anaplasma phagocytophilum in animals by real-time polymerase reaction. APMIS 2004, I | 2:239-247.

45. Liz JS, Anderes L, Sumner JW, Massung RF, Gern L, Rutti B, Brossard M: PCR detection of granulocytic Ehrlichia in Ixodes ricinus ticks and wild small mammals in wester Switzerland. J Clin Microbiol 2000, 38: 1002-1007.

46. Ogden NH, Casey ANJ, Woldehiwet Z, French NP: Transmission of Anaplasma phagocytophilum to Ixodes ricinus ticks from sheep in the acute and post acute phases of infection. Anaplasma phagocytophilum 2003, 71:207 I-2078.

47. Paulauskas A, Radzijevskaja J, Rosef O: Anaplasma in ticks feeding on migrating birds and questing ticks in Lithuania and Norway. Clin Microbiol Infect 2009, I 5(SuppI I):.

Publish with Bio Med Central and every scientist can read your work free of charge

"BioMed Central will be the most significant development for disseminating the results of biomedical research in our lifetime. "

Sir Paul Nurse, Cancer Research UK

Your research papers will be:

- available free of charge to the entire biomedical community

- peer reviewed and published immediately upon acceptance

- cited in PubMed and archived on PubMed Central

- yours - you keep the copyright

Submit your manuscript here:

http://www.biomedcentral.com/info/publishing_adv.asp
BiolMedcentral 